\title{
Combined Effect of Aqueous Extracts of Artemisia monosperma and Mentha piperita on the Reproductive Integrity of Male Albino Rats
}

\author{
Hagar E. Mohammed ${ }^{1}$, Ranwa A. Elrayess² and Heba N. Gad El-Hak ${ }^{2 *}$ \\ ${ }^{1}$ Zoology department, Faculty of Science, Arish University, North Sinai, Egypt \\ ${ }^{2}$ Zoology Department, Faculty of Science, Suez Canal University, Ismailia, Egypt
}

\begin{abstract}
A B S T R A C T
The aim of this study was to evaluate the effect of combinations of Artemisia monospermia with Mentha piperita on male fertility. Treated rats with different doses of A. monosperma or M. piperita alone induced severe testes histopathological lesions and histochemical alteration associated with a reduction in epididymis weight, abnormality in the sperm indices and a decline in serum testosterone levels which may have a bad impact on male infertility, on the other side, treatment the rats with the combined extract of different doses of $A$. monosperma or M. piperita attenuated the deleterious damage to the testes, the sperm index and the sex hormones. This study indicated that the traditional use of these two herbs as a mixture has no effects on male reproductive health.
\end{abstract}

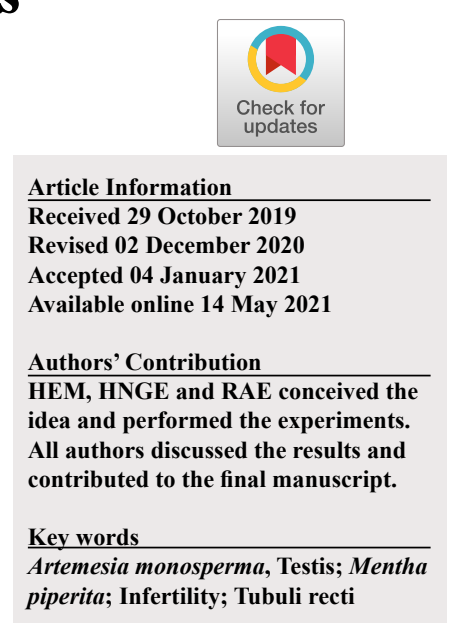

\section{INTRODUCTION}

$\mathrm{H}^{-1}$ erbal drug therapy is a common practice adopted in traditional and alternative medicine and has been used in the treatment of many diseases from ancient times (Pan et al., 2014; Gad-EL-Hak and Mobarak, 2020). Artemisia monospermia and Mentha piperita are two commen herbs.

A. monosperma is a common perennial shrub in the deserts (Huang et al., 2000) and one of the most common medicinial species of Artemisia used in folk medicine. Artemisia are aromatic fragrant plants that have a characteristic scent and taste (El-Massry et al., 2002). Some Artemisia species are used medically in repelling parasites (Goud and Swamy, 2015), in getting rid of intestinal gases and a gusher of menstruation (Nageeb et al., 2013), recommended for neurological disorders (Salah and Jäger, 2005), treatment of diabetes mellitus (Ribnicky et al., 2006), used as a cure against rheumatism (Adams et al., 2009) and to treat cold (Ballabh and Chaurasia, 2007). Some Artemisia species are used in traditional medicine as decoction for their antivenom (Nalbantsoy et al., 2013), anti-inflammatory (Choi et al., 2013) and antimicrobial (Ramezani et al., 2004) properties. It has been reported that different species of Artemisia grow wild in the uncultivated land have medicinal properties like anticholesterolemic (Riahi et al., 2013), antipyretic (Tan et al., 1998), antiseptic (Kordali et al., 2005) and used in the treatment of hepatitis (Mannan et al., 2010) and jaundice

\footnotetext{
Corresponding author: heba_nageh@hotmail.com 0030-9923/2021/0004-1329 \$ 9.00/0

Copyright 2021 Zoological Society of Pakistan
}

(Hayat et al., 2009). Artemisia should be taken carefully due to the santonin present, which has toxic effects if it is taken regularly (Hammond et al., 1997).

Mentha piperita (peppermint) is an important medicinal herb belongs to family Laminaceae, and commonly known as peppermint (Mimica-Dukic and Bozin, 2008). Peppermint is famous used as food additives in the form of spices (Kunnumakkara et al., 2009), flavoring enhancers (Kermode, 1972) and coloring agents (Oppenheimer et al., 1990) depend on common practice in human beings need. $M$. piperita act as preservatives (Sessou et al., 2012) and stomach carminatives (Girme et al., 2006). Peppermint has been consumed by many people in water by either as a juice or raw leaf addition in the tea and other herbs (Akdogan et al., 2004). M. piperita has a toxic effect on the testis (Akdogan et al., 2004) by causing a significant oligozoospermia (Ogbuewu et al., 2011) in experimental animals. Earliar studies indicated the structural alterations in testicular tissues, morphological deformities and inhibition of spermatogenesis of different mammalian species treated with peppermint (Sharma and Jacob, 1996; Sharma and Jocob, 2001).

The present study deals with impact of these two herbs administered in combination on the male fertility of albino rats.

\section{MATERIALS AND METHODS}

\section{Plant collection and prepration of plant extract}

A. monosperma and $M$. piperita aerial parts were collected from the northern Sinai desert, Arish of Egypt, in December 2018. It was authenticated by morphology 
and taxonomic elements in the Botany Department of Arish University, according to morphology and taxonomic aspects. Voucher specimens were deposited in the Herbarium of Faculty of Science, Arish University, North Sinai, Egypt with an accession number (2018001).

The aerial parts of Artemisia monosperma were airdried under the shade and grinded into fine powder using electric blender. Approximately $50 \mathrm{~g}$ of Artemisia powder placed in a flask with $1000 \mathrm{ml}$ distilled water, then boiled for $15 \mathrm{~min}$, then the mixture was filtered three times, The final concentration of prepared Artemisia monosperma was $5 \%$ as a total solids. The A. monosperma extract was preserved in a sterile dark bottle $(500 \mathrm{ml})$ in a cool environment $\left(4^{\circ} \mathrm{C}\right)$ until further use.

The leaves of $A$. monosperma were washed, wiped dry and cut the roots before immediately immerged into tap water. The concentration of the extract prepared was at $100 \mathrm{mg} / \mathrm{ml}$ which is corresponding to the daily recommended intake $200 \mathrm{ml}$ for adult man (Barbalho et al., 2011). The water extract was then filtered into a bottle and kept for about one hour before use. Dose of $290 \mathrm{mg} /$ $\mathrm{kg}$ b.wt. proven to be safe in a study of 14 days for all body organs (Johari et al., 2015).

\section{Animals and treatments}

Forty healthy adult male Spargue-Dawely rats were obtained from the animal house of the Zoology Department, Faculty of Science, Suez Canal University Ismailia, Egypt. They were housed in groups five per cage, maintained under controlled conditions of temperature (22 $\pm 2^{\circ} \mathrm{C}$ ) and light (12 dark: 12 light) in well ventilated room and provided with rodent food and water ad libitium. All animal experiments were carried out in accordance and approved with the guidelines of the Institutional Animals Ethics Committee of Faculty of Science, Suez Canal University Ismailia, Egypt. The animal experiments were performed according to the principles of the care and use of laboratory animals established by the National Institutes of Health (NIH Publication, No. 85-23, revised 1985) (Care et al., 1985). The animals were weighted and their behavioral changes were recorded before the start and at the end of the experiment with animal weighting balance. Animals were divided into eight groups of five rats each into: control group: rats were orally given distilled water. $\mathrm{AL}$ group: rats were orally given $100 \mathrm{mg} / \mathrm{kg}$ aqueous extract of $A$. monosperma daily for 2 weeks. AM group: rats were orally given $300 \mathrm{mg} / \mathrm{kg}$ aqueous extract of $A$. monosperma daily for 2 weeks. AH group: Rats were orally given $600 \mathrm{mg} / \mathrm{kg}$ aqueous extract of $A$. monosperma daily for 2 weeks. M group: Rats were orally given $M$. piperita at a dose level of $290 \mathrm{mg} / \mathrm{kg}$ daily for 2 weeks. ALM group: Rats were given the same dose of $A$. monosperma given to animals of group AL followed by $290 \mathrm{mg} / \mathrm{kg} M$. piperita daily for 2 weeks. AMM group: Rats were given the same dose of the same dose of $A$. monosperma given to animals of group AM followed by $290 \mathrm{mg} / \mathrm{kg}$ M. piperita daily for 2 weeks. AHM group: Rats were given the same dose of $A$. monospermia given to animals of group AH and $290 \mathrm{mg} / \mathrm{kg} \mathrm{M}$. piperita daily after 2 weeks he selected doses of A. monosperma according to the studied LD50 of A. monosperma to the rats which is more than $900 \mathrm{mg} / \mathrm{kg}$. Animals were anaesthetized by intraperitoneal injection of Ketamine $(50 \mathrm{mg} / \mathrm{kg}$ ) (Struck et al., 2011). Blood samples were collected in the morning by cardiac puncture into a set of plain sample bottles, and allowed to clot. The clotted blood samples were centrifuged to obtain serum. The separated serum samples were stored in the refrigerator until required for the hormonal assay. All assays were done within $24 \mathrm{~h}$ of the sample collection. The serum samples were assayed for FSH, LH and testosterone using enzymes immunoassay methods. Calculations of the concentrations of hormones were made according to the method given in the immunoassay kit's instruction.

\section{Sperm indices (sperm kinetics and morphology)}

Epididymides were dissected out, weighed, immediately minced in $5 \mathrm{ml}$ of physiological saline and then incubated at $37{ }^{\circ} \mathrm{C}$ for $30 \mathrm{~min}$ to allow spermatozoa to leave the epididymal tubules. The sperm indices were evaluated using computer-assisted SpermVision ${ }^{\mathrm{TM}}$ CASA System (CASA) (MiniTüb, Tiefenbach, Germany) with Olympus BX 51 phase contrast microscope (Olympus, Tokyo, Japan). Sperm kinetics parameters were determined which included the percentage of total motile spermatozoa (MT), the percentage of progressive motility (PR) is spermatozoa moving actively either linearly or in large circle regardless of speed, velocity curved line (VCL, $\mu \mathrm{m} / \mathrm{s}$ ), velocity straight line (VSL, $\mu \mathrm{m} / \mathrm{s}$ ), velocity average path (VAP, $\mu \mathrm{m} / \mathrm{s}$ ), distance curved line (DCL, $\mu \mathrm{m})$, distance straight line (DSL, $\mu \mathrm{m}$ ), distance average path (DAP, $\mu \mathrm{m}$ ), mean angular degree (MAD, ${ }^{0}$ ), amplitude of lateral head displacement (ALH, $\mu \mathrm{m})$, beat cross frequency $(\mathrm{BCF}, \mathrm{Hz})$, linearity (LIN, \%), wobble (WOB, \%) and straightness $(\mathrm{STR}=\mathrm{VSL} / \mathrm{VAP} \%)$.

Spermatozoa from each rat were examined morphology and individually scored normal or abnormal, according to the strict sperm morphology criteria. The morphological abnormalities were divided into head, midpiece and tail defects. The percentages of normal and abnormal shaped sperms, the multiple abnormalities per abnormal spermatozoa (MDI), the total number of defects divided by the number of sperm counted (TZI), the total number of defects divided by the number of sperm counted (SDI) was calculated. 


\section{Histological examination of tests}

The testes and the epidydimis of dissected rats were removed, cleaned of accessory tissues and weighed. The gonadosomatic index was calculated by dividing the testis and epidydimis weight by body weight of each animal getting the relative weight of testes and epididymis. The testes and the rete tubules were processed for histological examination according to Gad El-Hak and Mobarak (2020) and were stained with haematoxylin and eosin for the histopathological studies. For the histochemical investigations of testes, the deparaffinised sections were stained with blue Feulgen technique for DNA using Teomics kits according to the kits instruction and periodic acid Schiff's (PAS) for demonstration of polysaccharides (ElHak, 2017). While For the histochemical investigations of the rete testes, the deparaffinised section were stained with silver nitrate stain for reticular fibre (Elder and Hsu, 1981).

\section{Stastistical analysis}

The body weights and organ weight were expressed as the mean \pm standard error. The parametric data analyzed by One Way ANOVA subsequent Multiple comparison by Duncan test. The nonparametric data analyzed by KruskalWallis test and subsequent individual comparison by the Mann-Whitney U-test using SPSS statistical version 16 software package (SPSS 4 Inc., USA). $A p \leq 0$. 05 was considered to be statistically significant.

\section{RESULTS}

\section{Body and organ weights}

Table I shows effect of $A$. monosperma and Mentha piperita administered alone or in combition on body and organ weight. There was non-significant increase $(p \geq 0$. 05 ) in the initial and final body weight, relative testicular weight of rat in all the treated group when compared with the control group.

\section{Serum sex hormones}

Table II shows the effects of $A$. monospermia and $M$. piperita alone or combined on serum sex hormones of male rats. The results showed that there was no significant difference $(p \leq 0.05)$ in FSH and LH levels in all treated groups compared to control group, while testosterone level was significantly dropped $(p<0.05)$ in the $A$. monospermia groups (AL , AM and $\mathrm{AH})$ and mint group (M) compared to control group.

\section{Sperm indices}

Sperm of treated and control rats were evaluated through the sperm class analyzer for progressive kinetics and for sperm morphology Tables III and IV. The sperm kinetics analysis showed significant changes in all motion parameters of treated rats compared to control group. There was a significant decrease in MT and PR $(P<0.05)$ in M group. Also, there were increased distance parameters, including DAP $(P<0.05)$ in ALM, AM and AH groups, decrease in DCL $(P<0.05)$ in AMM, AHM and M groups, and increased DSL $(P<0.005)$ in ALM group. While there were significant decrease in STR $(P<0.005)$, LIN $(P<0.005)$, ALH $(P<0.05)$ and BCF $(\mathrm{P}<0.005)$ in $\mathrm{M}, \mathrm{AL}$, $\mathrm{A}, \mathrm{AH}, \mathrm{AMM}$ and AHM groups.

Table I. Effet of Artemesia monosperma and Mentha piperita extracts administered alone or in combination for 14 days on initial and final body weight, the relative testicular and epidydimal weight in rats of different groups after 14 days treatment.

\begin{tabular}{lllll}
\hline Groups & $\begin{array}{l}\text { Initial } \\
\text { body } \\
\text { weight (g) }\end{array}$ & $\begin{array}{l}\text { Final body } \\
\text { weight (g) }\end{array}$ & $\begin{array}{l}\text { Relative } \\
\text { testicular } \\
\text { weight (\%) }\end{array}$ & $\begin{array}{l}\text { Relative } \\
\text { epidydimal } \\
\text { weight (\%) }\end{array}$ \\
\hline Control & $268 \pm 12.7$ & $269 \pm 16.6$ & $1.93 \pm 0.2$ & $0.414 \pm 0.1$ \\
M & $279 \pm 16.9$ & $301 \pm 36.9$ & $1.63 \pm 0.3$ & $0.390 \pm 0.04$ \\
AL & $274 \pm 19.1$ & $267 \pm 20.7$ & $2.17 \pm 0.1$ & $0.365 \pm 0.01$ \\
AM & $249 \pm 17.42$ & $286 \pm 28.1$ & $2.07 \pm 0.1$ & $0.450 \pm 0.04$ \\
AH & $278 \pm 23.8$ & $318 \pm 68.4$ & $1.85 \pm 0.2$ & $0.566 \pm 0.04$ \\
ALM & $276 \pm 15.1$ & $295 \pm 25.4$ & $2.13 \pm 0.1$ & $0.482 \pm 0.1$ \\
AMM & $258 \pm 32.6$ & $275 \pm 75.2$ & $1.85 \pm 0.2$ & $0.566 \pm 0.05$ \\
AHM & $268 \pm 11.8$ & $271 \pm 34.1$ & $1.84 \pm 0.2$ & $0.482 \pm 0.01$ \\
\hline
\end{tabular}

$\overline{\mathrm{M}, \text { M.piperita extract with dose } 290 \mathrm{mg} / \mathrm{kg} / \text { day for } 14 \text { days; } \mathrm{AL}, \text { A. monospermia }}$ extract with dose $100 \mathrm{mg} / \mathrm{kg}$ /day for 14 days; AM, A. monospermia extract with dose $300 \mathrm{mg} / \mathrm{kg} /$ day for 14 days; $\mathrm{AH}, A$. monospermia extract with dose $600 \mathrm{mg} / \mathrm{kg} /$ day for 14 days; ALM, A. monospermia extract with dose $100 \mathrm{mg} /$ $\mathrm{kg} /$ day $+M$. piperita extract with dose $290 \mathrm{mg} / \mathrm{kg} /$ day for 14 days; AMM, A. monospermia extract with dose $300 \mathrm{mg} / \mathrm{kg} /$ day + M. piperita extract with dose $290 \mathrm{mg} / \mathrm{kg} /$ day for 14 days; AHM, A. monospermia extract with dose $600 \mathrm{mg} / \mathrm{kg} /$ day + M. piperita extract with dose $290 \mathrm{mg} / \mathrm{kg} /$ day for 14 days.

Table II. Effects of Artemesia monosperma or Mentha piperita extracts administered alone or in combined for 14 days on serum sex hormones of male albino rats.

\begin{tabular}{llll}
\hline Groups & FSH $(\mathbf{m I U} / \mathbf{m l})$ & $\mathbf{L H}(\mathbf{m I U} / \mathbf{m l})$ & Testosterone $(\mathbf{n g} / \mathbf{d l})$ \\
\hline Control & $0.005 \pm 0.002$ & $0.003 \pm 0.0001$ & $0.522 \pm 0.06^{\mathrm{c}, \mathrm{d}}$ \\
M & $0.003 \pm 0.001$ & $0.004 \pm 0.0001$ & $0.250 \pm 0.14^{\mathrm{a}}$ \\
AL & $0.004 \pm 0.001$ & $0.003 \pm 0.0004$ & $0.137 \pm 0.03^{\mathrm{a}}$ \\
AM & $0.0035 \pm 0.003$ & $0.005 \pm 0.0006$ & $0.272 \pm 0.22^{\mathrm{a}, \mathrm{b}}$ \\
AH & $0.005 \pm 0.004$ & $0.003 \pm 0.0001$ & $0.334 \pm 0.21^{\mathrm{a}, \mathrm{b}, \mathrm{c}}$ \\
ALM & $0.006 \pm 0.001$ & $0.004 \pm 0.0001$ & $0.546 \pm 0.09^{\mathrm{d}}$ \\
AMM & $0.005 \pm 0.001$ & $0.033 \pm 0.029$ & $0.454 \pm 0.154^{\mathrm{b}, \mathrm{c}, \mathrm{d}}$ \\
AHM & $0.006 \pm 0.004$ & $0.004 \pm 0.0007$ & $0.518 \pm 0.041^{\mathrm{c}, \mathrm{d}}$ \\
\hline
\end{tabular}

Data is represented ad mean \pm SE. different letters represent significant $(\mathrm{P}$ $<0.005$ ) compared to the control group. For details of groups, see Table I. 
The sperm of rats from the AL and ALM showed nonsignificant increases $(P<0.05)$ in VAP and VCL, consistently with ALH $(P<0.005)$ while, BCF values were significantly decreased $(P<0.05)$. There was no significant difference in MOT and PR parameters in the groups M, AHM, AM and AL compared to control. Furthermore, ALH parameter was significantly decreased $(P<0.005)$ in $\mathrm{M}, \mathrm{AL}, \mathrm{AM}, \mathrm{AH}, \mathrm{AMM}$ and AHM groups. Conversely, significant decreases were detected in progression parameters VSL $(P<0.05)$ in M, AM, AH, AMM and AHM groups, decreased LIN $(P<0.005)$ and vigor parameters WOB $(\mathrm{P}<0.005)$ in $\mathrm{M}, \mathrm{AM}$ and $\mathrm{AL}$ groups and decreased BCF $(P<0.005)$ in $\mathrm{M}, \mathrm{AL}, \mathrm{AM}, \mathrm{AH}, \mathrm{ALM}, \mathrm{AMM}$ and AHM groups compared to control.

\section{Sperm morphology}

The evaluations of normal and abnormal spermatozoa are shown in Table IV. Morphological analysis of semen samples revealed a significantly lower percentage of spermatozoa with abnormal morphology in all experimental groups $(P<0.005)$. The significantly increased incidence of sperm with abnormalities in M group were detected. Treatment with Artemesia alone or with Mint did not produce any variation in the frequency of the sperm head, tail and midpiece abnormalities.

\section{Histological and histochemical examination of testis}

Histological examination of testicular section of control rats showed the normal histological testicular architecture with normally arrangement different series of spermatogenic layers, spermatozoa and the interstitial tissues with Leydig cells (Fig. 1A). Testis of rats treated with Artemisia (Fig. 1C, 1D and 1E) or mint (Fig. 1B) showed testicular degeneration of germ cells within the seminiferous tubules which were greatly depleted of germ cells. Some treated rats showed disturbance in the arrangement of germ cell rows of spermatogenic cells which appears as areas lacking spermatogenic activity with exfoliation of cells in many of the tubules. While testicular examination of rats which received a combined dose of Artemisia sp. and Mint showed normal seminiferous tubules with normally arrangement different series of spermatogenic layers (Fig. 1F, 1G and 1H).

Figure 2 shows Quantitative evaluation of Polysaccharides PAS-positive materials in the testes of control rat and in those given the combination of Artemisia sp. and peppermint aqueous extract appeared increase in the basement membrane of the tubules (the tunica albuginea) as well as in the intertubular connective tissue of the testes. Testes of rats treated with peppermint aqueous extract only and doses of Artemisia revealed a mild decrease of PASpositive materials.

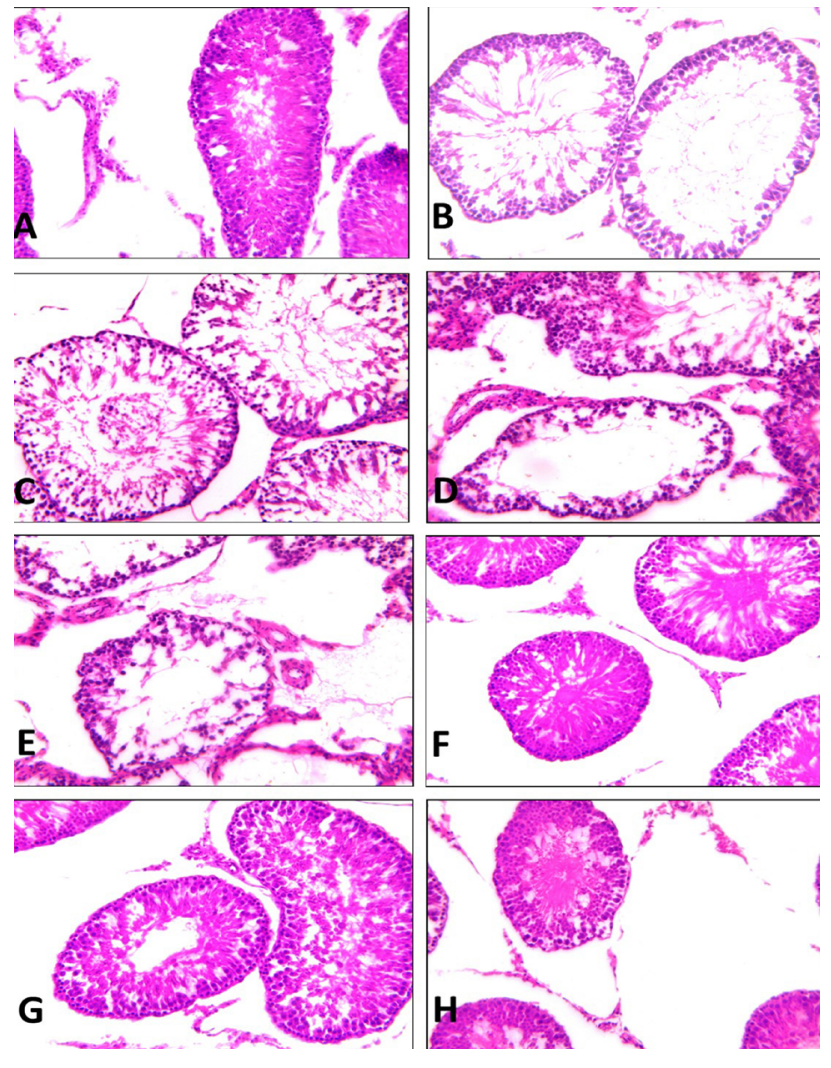

Fig. 1. (A) Testis of control rats showing the normal histological structure of seminiferous tubules with different series of active spermatogenic layers, spermatozoa and the interstitial tissues. (B) Testis of mint treated group showing alternations of some tubules in the form of reduced the number of layers of the germinal epithelium, spermatozoa with vacuolated spermatogenic cells. (C, D and E) Testis of AL, AM and AH group showing tubular shrinkage with extensive degeneration of the germinal epithelium. The shrinkage tubules contained degenerated Sertoli cells with few germ cells. (F, G and H) Testis of ALM, AMM and AHM group showing no prominent histological changes. Most of the seminiferous tubules appeared to increase of spermatogenic cells and an increase in the number of sperm bundles was seen. (Stain HX and magnification x200).

DNA deoxyribose sugar was histochemically demonstrated using the blue Feulgen reaction technique (Fig. 3). The DNA present in the nucleus of spermatogonia and spermatocytes. The mean DNA content of spermatogonia and spermatocyte in all treated groups was the same as the control group.

Figure 4 shows the histological examination of the tubuli recti in the control and the treated rats with the combination of Artemisia sp. Peppermint groups did not show any histological damage. The histological examination on the tubuli recti in $\mathrm{M}, \mathrm{AL}, \mathrm{AM}$ and $\mathrm{AH}$ groups reduced 
sperm reserves relative to the control and vacuolation appeared in the cuboidal epithelium lining the tubules.

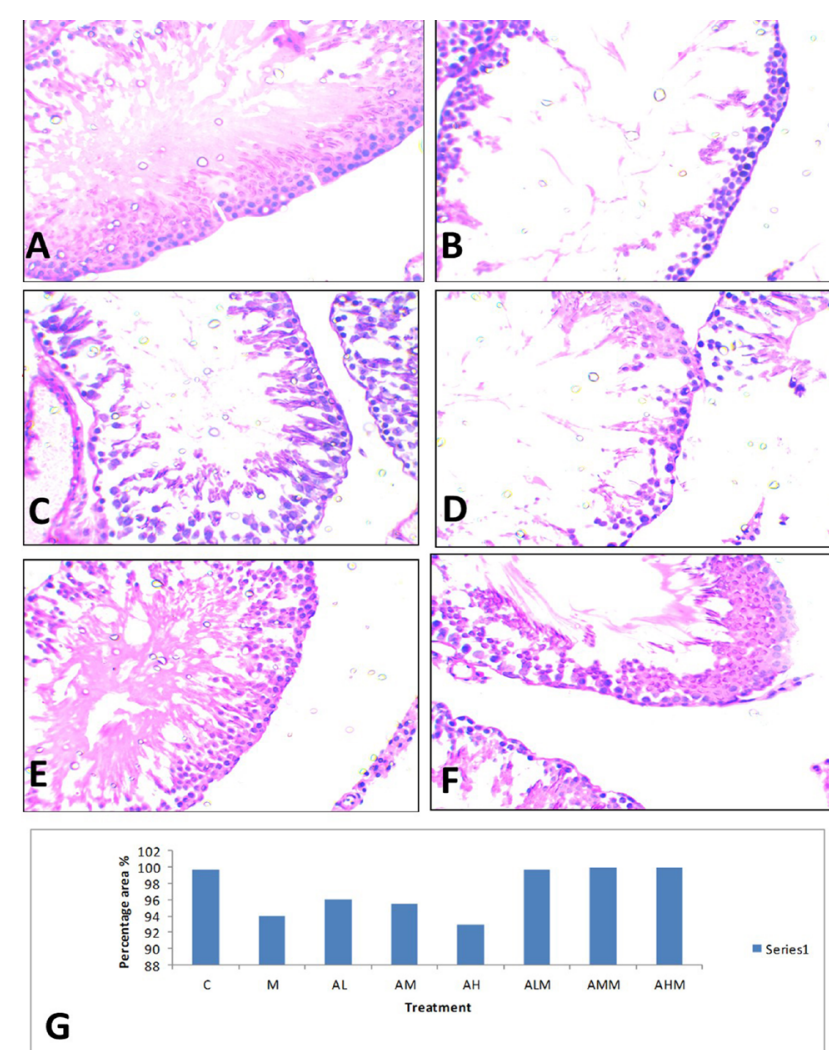

Fig. 2. Cross sections from testis, (A) control group with positive PAS increase in the basement membrane of the tubules (the tunica albuginea) as well as in the intertubular connective tissue of the testes. (B, C, D and E) Testis of mint, $\mathrm{AL}, \mathrm{AM}$ and $\mathrm{AH}$ treated group showing decrease PAS reaction. (F, G and $\mathrm{H}$ ) Testis of ALM, AMM and AHM group showing normal positive PAS. (PAS staining technique, 400X). (I) Percentage of PAS stained area in the treated group.

Figure 5 shows silver stains of the tubuli recti showed strong stain which revealed the presence of extensive and dense network of reticular fibers around the peritubular walls of the control and the treated rats with the combination of Artemisia sp. and peppermint groups. The tubuli recti in $\mathrm{M}, \mathrm{AL}, \mathrm{AM}$ and $\mathrm{AH}$ groups showed fragmented and degenerated reticular fibers with weal stained area with silver nitrate stained area.

\section{DISCUSSION}

Various tissue and organ systems of an individual differ in their response to herbal treatment, especially organs characterized by high cell proliferation. Testis considered one of the most sensitive organ due to its rapidly dividing cell renewal system.

In this study, the reproductive toxicity was conducted prior to assessment of aqueous extract of peppermint, different doses of $A$. monosperma and combination the different dose of $A$. monosperma with peppermint. The results showed that there was no sign of toxicity, no mortality within the entire period of 14 days of herbs administration. The extract did not trigger any changes in behavior, breathing, cutaneous effect, urination and defecation and did not suppress their appetite or retard their development. Neither body weight nor relative weights of testes and epidydimis of treated rats were significantly changed relative to the control group as the relative weight is a measure of the health status of the organ (EL-Hak et al., 2019).

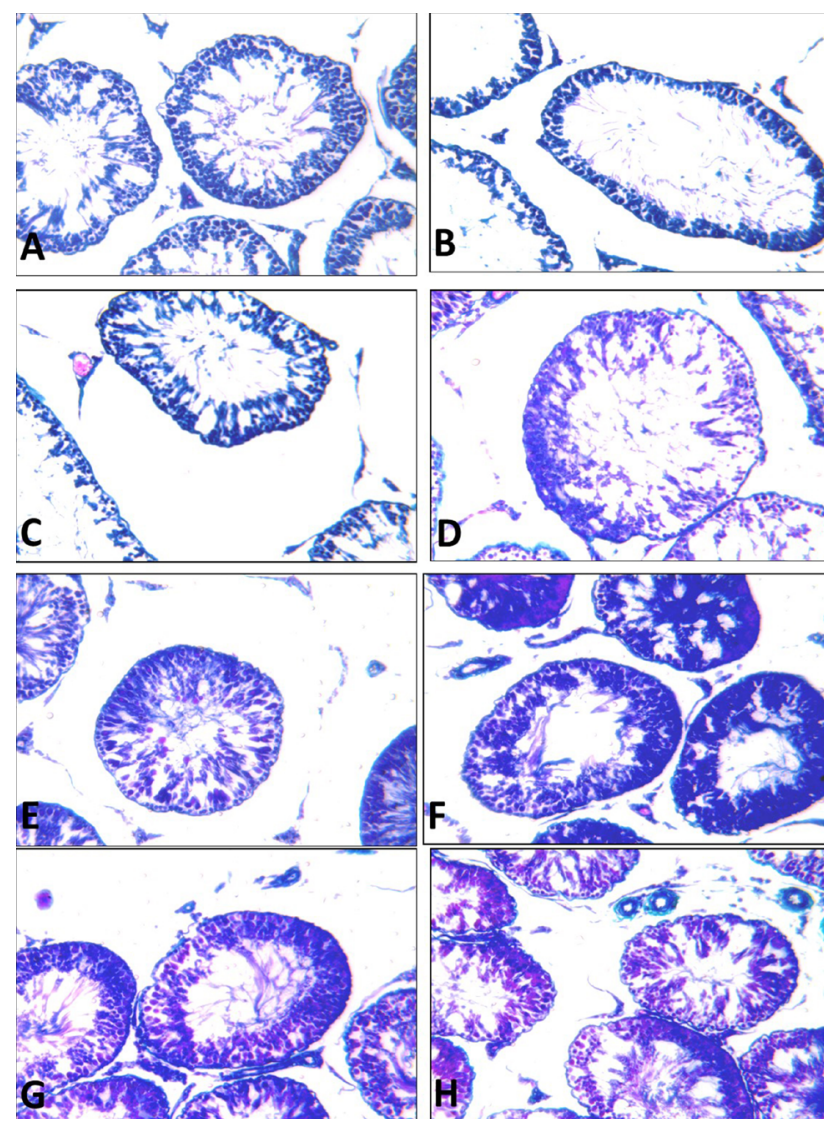

Fig. 3. Cross sections from testis, (A) control group with positive Feulgen reaction in the nucleus of spermatogonia and spermatocytes. (B, C, D and E) Testis of mint, AL, AM and $\mathrm{AH}$ treated group showing a decrease in The intensity of DNA blue color. (F, G and H) Testis of ALM, AMM and AHM group showing normal positive Feulgen reaction. (Feulgen staining technique, 200X). 
Table III. Sperm Kinetics parameters for control rats and those treated with Artemesia monosperma or Mentha piperita extracts alone or in combination.

\begin{tabular}{lllllllll}
\hline Parameter & Control & M & AL & AM & AH & ALM & AMM & AHM \\
\hline MT $(\%)$ & $45.01 \pm 0.5$ & $17.7 \pm 5.4^{*}$ & $28.3 \pm 3.2^{*}$ & $24.6 \pm 4.0^{*}$ & $23.2 \pm 3.8^{*}$ & $29.7 \pm 10.6^{*}$ & $24.7 \pm 1.8^{*}$ & $31.7 \pm 3.2^{*}$ \\
PR $(\%)$ & $45.37 \pm 0.4$ & $23.09 \pm 5.8^{*}$ & $34.3 \pm 3.3$ & $26.4 \pm 5.7^{*}$ & $30.2 \pm 5.2^{*}$ & $35.2 \pm 4.5$ & $23.6 \pm 2.9^{*}$ & $29.1 \pm 2.1^{*}$ \\
VCL $(\mu \mathrm{m} / \mathrm{s})$ & $23.03 \pm 0.5$ & $9.45 \pm 3.0^{*}$ & $13.35 \pm 1.4^{*}$ & $12.9 \pm 1.6^{*}$ & $11.2 \pm 2.5^{*}$ & $17.26 \pm 3.2$ & $11.56 \pm 2.8^{*}$ & $16.8 \pm 2.5$ \\
VSL $(\mu \mathrm{m} / \mathrm{s})$ & $2.76 \pm 0.2$ & $1.030 \pm 0.1^{*}$ & $2.27 \pm 0.37$ & $1.58 \pm 0.41^{*}$ & $1.48 \pm 0.28^{*}$ & $2.141 \pm 0.45$ & $1.25 \pm 0.12^{*}$ & $1.24 \pm 0.07^{*}$ \\
VAP $(\mu \mathrm{m} / \mathrm{s})$ & $4.05 \pm 0.1$ & $2.25 \pm 0.5^{*}$ & $3.49 \pm 0.4$ & $2.53 \pm 0.5^{*}$ & $2.63 \pm 0.4^{*}$ & $2.79 \pm 0.4$ & $1.84 \pm 0.24^{*}$ & $2.44 \pm 0.1^{*}$ \\
DCL $(\mu \mathrm{m})$ & $26.54 \pm 1.4$ & $12.98 \pm 3.1$ & $22.1 \pm 2.6$ & $15.85 \pm 4.1$ & $15.77 \pm 2.3$ & $18.45 \pm 1.8$ & $12.39 \pm 1.2$ & $13.76 \pm 1.08$ \\
DSL $(\mu \mathrm{m})$ & $0.577 \pm 0.09$ & $1.60 \pm 0.6$ & $1.60 \pm 0.4$ & $2.71 \pm 0.2^{*}$ & $3.34 \pm 0.8^{*}$ & $3.69 \pm 0.7^{*}$ & $2.14 \pm 0.45$ & $1.59 \pm 0.8$ \\
DAP $(\mu \mathrm{m})$ & $0.265 \pm 0.08$ & $0.50 \pm 0.2$ & $0.65 \pm 0.2$ & $1.15 \pm 0.1^{*}$ & $1.29 \pm 0.2^{*}$ & $1.13 \pm 0.2^{*}$ & $0.58 \pm 0.08$ & $0.80 \pm 0.4$ \\
MAD $(\%)$ & $1.22 \pm 0.4$ & $2.96 \pm 2.7$ & $3.52 \pm 2.6$ & $5.57 \pm 1.7$ & $7.20 \pm 3.7^{*}$ & $7.31 \pm 4.2^{*}$ & $4.21 \pm 1.6^{*}$ & $3.38 \pm 3.2$ \\
ALH $(\mu \mathrm{m})$ & $4.76 \pm 0.3$ & $2.21 \pm 0.4^{*}$ & $3.15 \pm 0.4^{*}$ & $2.03 \pm 0.4^{*}$ & $2.49 \pm 0.5^{*}$ & $3.45 \pm 0.6$ & $2.7 \pm 0.4^{*}$ & $2.5 \pm 0.4^{*}$ \\
BCF $(\mathrm{Hz})$ & $2.22 \pm 0.1$ & $0.75 \pm 0.1^{*}$ & $1.11 \pm 0.1^{*}$ & $0.88 \pm 0.1^{*}$ & $0.92 \pm 0.1^{*}$ & $1.54 \pm 0.3^{*}$ & $1.07 \pm 0.2^{*}$ & $1.25 \pm 0.1^{*}$ \\
LIN $(\%)$ & $10.78 \pm 1.06$ & $4.06 \pm 0.5^{*}$ & $6.88 \pm 1.05^{*}$ & $4.45 \pm 0.94^{*}$ & $4.71 \pm 1.01^{*}$ & $6.78 \pm 1.07^{*}$ & $5.61 \pm 0.91^{*}$ & $5.40 \pm 1.8^{*}$ \\
WOB $(\%)$ & $4.58 \pm 0.8$ & $0.8 \pm 0.4$ & $0.67 \pm 0.1$ & $1.38 \pm 0.6$ & $2.02 \pm 0.7^{*}$ & $4.39 \pm 1.5^{*}$ & $2.56 \pm 1.06^{*}$ & $2.06 \pm 0.5^{*}$ \\
STR $(\%)$ & $32.4 \pm 2.63$ & $16.4 \pm 3.4^{*}$ & $15.8 \pm 1.44^{*}$ & $17.5 \pm 3.5^{*}$ & $16.1 \pm 2.98^{*}$ & $28.3 \pm 4.4$ & $19.5 \pm 3.4^{*}$ & $17.7 \pm 3.2^{*}$ \\
\hline
\end{tabular}

Data is represented ad mean \pm SE. $\left(^{*}\right)$ significant $(P<0.005)$ compared to the control group. For details of groups, see Table I.

MT, motile spermatozoa; PR, progressive motility; VCL, velocity curved line; DCL, distance curved line; DSL, distance straight line; DAP, distance average path; MAD, mean angular degree; ALH, amplitude of lateral head; BCF, beat cross frequency; LIN, linearity; WOB, wobble; STR, straightness.

Table IV. Effects of Artemesia monosperma or Mentha piperita extracts administered alone or in combintion on sperm morphology of male albino rats.

\begin{tabular}{lllllllll}
\hline Parameter & \multicolumn{9}{c}{ Group } \\
\cline { 2 - 9 } & Control & $\mathbf{M}$ & AL & AM & AH & ALM & AMM & AHM \\
\hline Head defect & $1.176 \pm 0.04$ & $1.10 \pm 0.00$ & $1.19 \pm 0.05$ & $1.11 \pm 0.01$ & $1.21 \pm 0.11$ & $1.30 \pm 0.2$ & $1.10 \pm 0.00$ & $1.61 \pm 0.02$ \\
Midpiece defect & $0.594 \pm 0.3$ & $0.00 \pm 0$ & $3.22 \pm 3.1$ & $0.82 \pm 0.8$ & $1.02 \pm 1.02$ & $1.02 \pm 1.02$ & $1.02 \pm 1.02$ & $1.02 \pm 1.02$ \\
Tail defect & $2.20 \pm 2$ & $5.80 \pm 5.8$ & $2.20 \pm 2.2$ & $21.82 \pm 7.2$ & $20.4 \pm 9.07$ & $17.8 \pm 9.1$ & $21.8 \pm 6.3$ & $7.6 \pm 3.1$ \\
MDI & $34.5 \pm 5.1^{*}$ & $39.8 \pm 9.2$ & $29.1 \pm 4.4$ & $3.75 \pm 2.7^{*}$ & $8.28 \pm 6.4^{*}$ & $9.89 \pm 4.77^{*}$ & $1.02 \pm 1.02^{*}$ & $8.02 \pm 4.1^{*}$ \\
TZI & $22.11 \pm 7.5$ & $47.06 \pm 7.4$ & $32.64 \pm 3.0$ & $25.4 \pm 5.7$ & $28.8 \pm 10.9$ & $27.5 \pm 7.1$ & $23.5 \pm 5.01$ & $19.1 \pm 4.4$ \\
SDI & $67.08 \pm 1.03$ & $52.9 \pm 7.4$ & $67.3 \pm 3.00$ & $74.5 \pm 5.7^{*}$ & $71.1 \pm 10.9$ & $72.8 \pm 7.4$ & $76.4 \pm 5.01^{*}$ & $80.8 \pm 4.4^{*}$ \\
\hline
\end{tabular}

Data is represented ad mean \pm SE. $(*)$ significant $(P<0.005)$ compared to the control group. For details of groups, see Table I.

The M, AL, AM and AH treated groups showed significant decreases in serum testosterone level which may have resulted from the direct effect of $M$. piperita and $A$. monosperma on Leydig cells according to Dym and Madhwa Raj (1977). These reduction in testosterone level may cause a decrease in libido, reproductive functions and hence resulting in impotence according to Blute et al. (2009).

In the present study, treatment with $M$. piperita and A. monosperma alone or in combination did not affect the level of LH and FSH. That may be according to previous results of Pradhan et al. (2013) that found Artemesia sp. suppresses feedback secretion of the pituitary which suppressed the regulatory changes in LH and FSH secretion.

In the present study, results indicate significant decline in sperm motility and morphology of rats treated with Artemesia sp., or peppermint which may be from the androgen deprivation effect and the decrease of testosterone (Handelsman et al., 1996). As the epididymal spermatozoa are highly dependent on testosterone for their final maturation and development of progressive motility and fertilizing capacity (Dyson and Orgebin-Crist, 1973). These findings are similar to those reported by D'cruz et 
al. (2010; Smith (2010); Ogbuewu et al. (2011) reported decrease in sperm concentration and motility, increase in dead and abnormal sperm of rats and impairment of spermatogenesis in animals treated with mint or Artemesia sp.
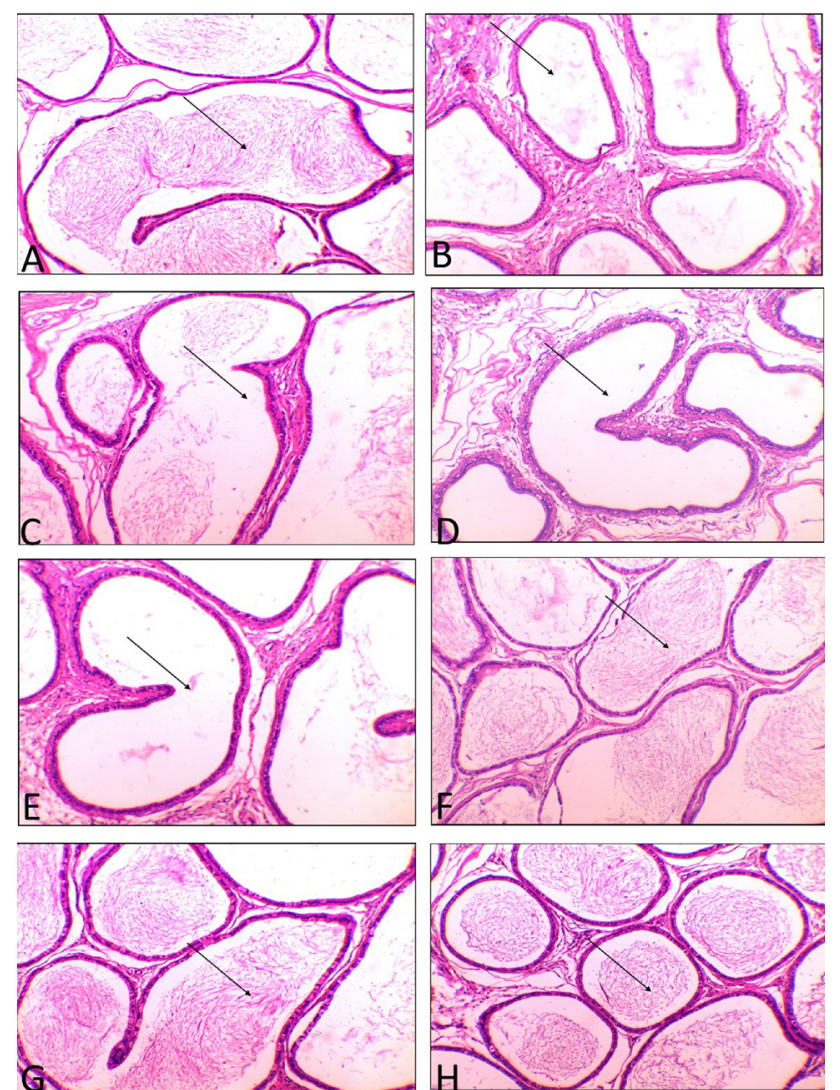

Fig. 4. (A) Tubuli recti of the control group showing the normal histological structure lining with cuboidal epithelium and present of sperm in the lumen $(\leftarrow)$. (B) Tubuli recti of mint treated group showing alternations of some tubules in the form of reduced sperm in the lumen $(\leftarrow)$. (C, D and E) Tubuli recti of AL, AM and AH group showing vacuolation of the cuboidal epithelium with extensive absent of the sperm in the lumen $(\leftarrow)$. (F, G and H) Tubuli recti of ALM, AMM and AHM group showing no prominent histological changes with increase of sperm in the lumen $(\leftarrow)$. (H and E, $\mathrm{x} 200)$.

The alteration in sperm parameters could be attributed to direct effect of these plants on testicular tissue which leads to reproductive dysfunction such as reduced sperm motility and increase sperm abnormailities in the morphology (Wong et al., 2000). The present study found that the combination of $A$. monospermia extract and $M$. piperita extract play a specific role in maintaining the structural and functional integrity of the sperm cell.
Treatment with combined Artemesia sp. and peppermint displayed a higher incidence of hyperactivated like motility than caused by Artemesia or peppermint alone. Interestingly, simultaneous treatment with Artemesia sp. or peppermint produces an adverse effect on the sperm morphology. The possibility that Artemesia sp. or peppermint may cross the epididymal epithelium based on its lipophilic properties and reach the stored spermatozoa would explain its damaging effects on sperm structure and function according to Adamkovicova et al. (2016). The fertilization capabilities of sperm were significantly reduced because of spermatozoa movement dysfunction and reduction of testosterone hormone (Fallah et al., 2018).

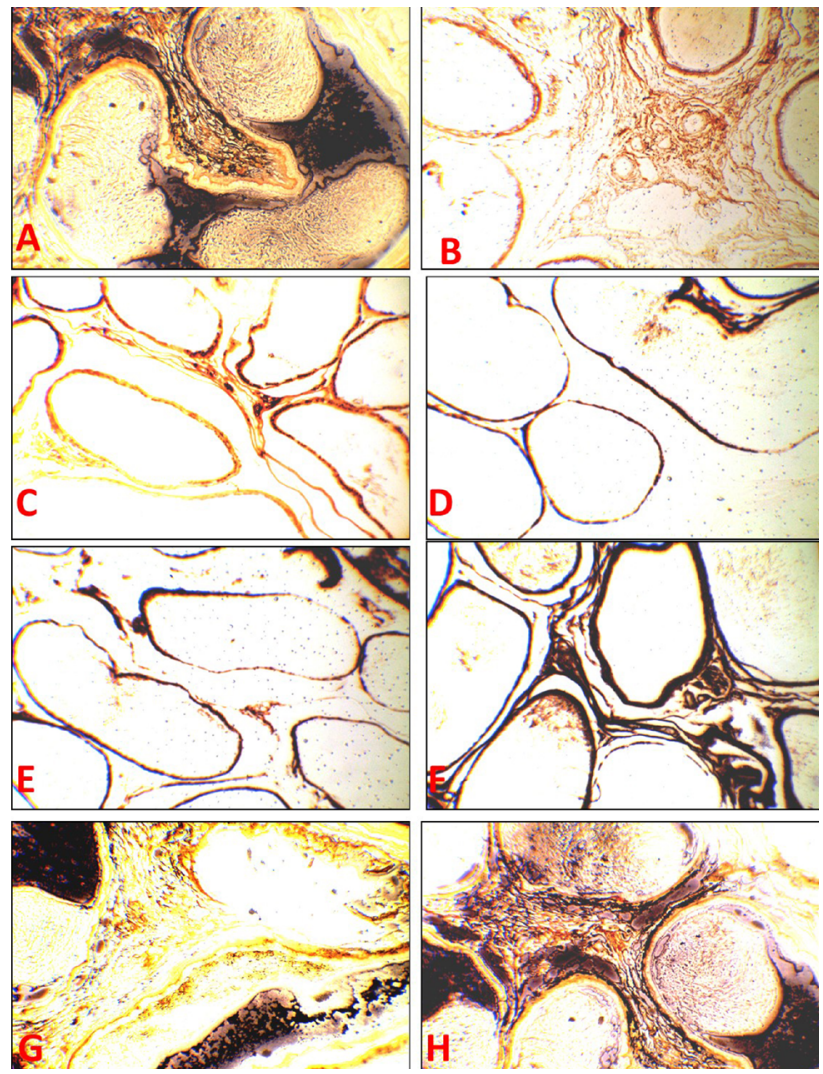

Fig. 5. (A) Tubuli recti of the control group showing normal reticular fibers. (B, C, D and E) Tubuli recti of M, AL, AM and $\mathrm{AH}$ group showing degeneration and fragmentation of reticular fibers (F, G and $\mathrm{H}$ ) Tubuli recti of ALM, AMM and AHM group showing the normal appearance of reticular fibers. (Silver stains x200).

In the present study using histological evaluation of testis, we observed that oral administration of peppermint or different doses of $A$. monosperma could exert adverse effects on spermatogenesis process and cause some histological changes. Control groups showed a compact 
and regular arrangement of spermatogenic cells in the seminiferous tubules whereas in peppermint or different doses of $A$. monosperma treatment groups, deceased cell layers and degeneration were observed. Histopathological examination showed a slight increase in the number of tubules with histologically disruption in the $\mathrm{AH}$ group. The explanation for this finding may be due to the indirect effect of decrease in the serum testosterone level in $\mathrm{M}, \mathrm{AL}, \mathrm{AM}$ and $\mathrm{AH}$ group which has been reported in the present study. Furthermore, reduced number of interstitial cells in $\mathrm{M}, \mathrm{AL}$, $\mathrm{AM}$ and $\mathrm{AH}$ treated groups which are testosterone secreting cells in the male reproductive system could be considered supporting evidence for the aforementioned finding. The histological examination of the different spermatogenic stages revealed that no stage was specifically susceptible to treatment with the extract. Exfoliation of germ cells was observed in the results of this study in the M, AL, AM and $\mathrm{AH}$ group and can be explained according to Li et al. (2016) who postulated that it may be due to disruption of cell junctions leading to loss of adhesion or it may be due to disruption of Sertoli cell cytoskeletal fibers leading to sloughing of apical Sertoli cell cytoplasm and attached germ cells. The mechanism by which A. monosperma or $M$. piperita extract produces lesions in the testes remains unclear but several factors may be considered. Decreased testosterone production has been proposed as the probable cause of damage to the seminiferous tubules of rats (Rich et al., 1979). In addition, data from the present study has indicated that serum testosterone levels were altered in rats. Rats treated with the combination of Artemisia sp. and peppermint aqueous extract showed normal seminiferous tubules. Our data point to the need to further analyze the exact effect of the biomolecules present in $A$. monosperma or $M$. piperita extract or combination of both extracts on the the male reproductive integrity individually or collectively. The rats treated with Mint or Artemesia showed diminution in percentage area of PAS +ve materials which can be explained according to Gupta et al. (2002) by impairment of spermatogenesis resulted from the decreased androgen concentration. Artemesia sp. with Mint gave a normal +ve result that can be explained by thickening of the basement membrane of seminiferous tubules. Histochemically, the rats treated with mint or Artemesia or both exhibit no difference in DNA content in testis as also reported by Cheville et al. (1998) and Tseng et al. (2006).

In the present study and decrease of sperm in the tubuli recti, degeneration of reticular fibres between the tubules were observed in M, AL, AM and AH groups. Tubuli recti, form the junction between the seminiferous tubules and the rete (Dym, 1974). The rete testis serves as a collecting reservoir for sperm within the testis (Free et al., 1980).
The Low Tubuli recti sperm density and degeneration of the reticular fibers may be due to alteration in the androgen metabolism (Scarano et al., 2006). In the other hand, ALM, AMM and AHM groups showed the presence of sperm and normal apperarnce of reticular fibres. Reticular fibers is important in the Tubuli recti to transmit the sperm in the male reproductive organ (Pathak et al., 2014).

\section{CONCLUSION}

The study revealed that administration of $A$. monospermia or $M$. piperita alone to male rats resulted in damage induced in rat testes and sperm quality that in the future may lead to reproductive integrity and infertility. In the other hand, the administration the mixture of both $A$. monospermia and Peppermint extract has the potential to prevent and antidote that damage.

Statement of conflict of interest

The authors have declared no conflict of interest.

\section{REFERENCES}

Adamkovicova, M., Toman, R., Martiniakova, M., Omelka, R., Babosova, R., Krajcovicova, V., Grosskopf, B. and Massanyi, P., 2016. Sperm motility and morphology changes in rats exposed to cadmium and diazinon. Reprod. Biol. Endocrinol., 14: 42-42. https://doi.org/10.1186/s12958-0160177-6 Available from https://www.ncbi.nlm.nih. gov/pubmed/27503218

Adams, M., Berset, C., Kessler, M. and Hamburger, M., 2009. Medicinal herbs for the treatment of rheumatic disorders a survey of european herbals from the $16^{\text {th }}$ and $17^{\text {th }}$ century. J. Ethnopharmacol., 121: 343-359. https://doi.org/10.1016/j.jep.2008.11.010

Akdogan, M., Ozguner, M., Kocak, A., Oncu, M. and Cicek, E., 2004. Effects of peppermint teas on plasma testosterone, follicle-stimulating hormone, and luteinizing hormone levels and testicular tissue in rats. Urology, 64: 394-398. https://doi. org/10.1016/j.urology.2004.03.046

Ballabh, B. and Chaurasia, O., 2007. Traditional medicinal plants of cold desert ladakh used in treatment of cold, cough and fever. $J$. Ethnopharmacol., 112: 341-349. https://doi. org/10.1016/j.jep.2007.03.020

Barbalho, S.M., Machado, F.M.V.F., Oshiiwa, M., Abreu, M., Guiger, E.L., Tomazela, P. and Goulart, R.A., 2011. Investigation of the effects of peppermint (mentha piperita) on the biochemical and anthropometric profile of university students. 
Fd. Sci. Technol., 31: 584-588. https://doi. org/10.1590/S0101-20612011000300006

Blute, M., Hakimian, P., Kashanian, J., Shteynshluyger, A., Lee, M. and Shabsigh, R., 2009. Erectile dysfunction and testosterone deficiency. In: Advances in the management of testosterone deficiency. Karger Publishers. pp. 108-122. https:// doi.org/10.1159/000176048

Care, I.O.L.A.R.C.O., Animals, U.O.L. and Resources, N.I.O.H.D.O.R., 1985. Guide for the care and use of laboratory animals. National Academies.

Cheville, J.C., Sebo, T.J., Lager, D.J., Bostwick, D.G. and Farrow, G.M., 1998. Leydig cell tumor of the testis: A clinicopathologic, DNA content, and mib-1 comparison of nonmetastasizing and metastasizing tumors. Am. J. Surg. Pathol., 22: 1361-1367. https:// doi.org/10.1097/00000478-199811000-00006

Choi, E., Park, H., Lee, J. and Kim, G., 2013. Anticancer, antiobesity, and anti-inflammatory activity of Artemisia species in vitro. J. Tradit. Chinese Med., 33: 92-97. https://doi.org/10.1016/ S0254-6272(13)60107-7

D'cruz, S.C., Vaithinathan, S., Jubendradass, R.and Mathur, P.P., 2010. Effects of plants and plant products on the testis. Asian J. Androl., 12: 468. https://doi.org/10.1038/aja.2010.43

Dym, M. and Raj, H.M., 1977. Response of adult rat sertoli cells and leydig cells to depletion of luteinizing hormone and testosterone. Biol. Reprod., 17: 676-696. https://doi.org/10.1095/ biolreprod17.5.676

Dym, M., 1974. The fine structure of monkey sertoli cells in the transitional zone at the junction of the seminiferous tubules with the tubuli recti. Am. J. Anat., 140: 1-25. https://doi.org/10.1002/ aja.1001400102

Dyson, A. and Orgebin-Crist, M-C., 1973. Effect of hypophysectomy, castration and androgen replacement upon the fertilizing ability of rat epididymal spermatozoa. Endocrinology, 93: 391402. https://doi.org/10.1210/endo-93-2-391

Elder, F. and Hsu, T., 1981. Silver-staining patterns of mammalian epididymal spermatozoa. Cytogenet. Genome Res., 30: 157-167. https://doi. org/10.1159/000131604

El-Hak, H.N.G., 2017. The protective effects of panax ginseng extract on fertility of albino rats treated with formaldehyde vapours. Egypt. J. Zool., 68: 221-238. https://doi.org/10.12816/0043190

EL-Hak, H.N.G., ELaraby, E.E., Hassan, A.K. and Abbas, O.A., 2019. Study of the toxic effect and safety of vitamin e supplement in male albino rats after 30 days of repeated treatment. Heliyon, 5: e02645. https://doi.org/10.1016/j.heliyon.2019. e02645

El-Massry, K.F., El-Ghorab, A.H. and Farouk, A., 2002. Antioxidant activity and volatile components of egyptian Artemisia judaica 1. Fd. Chem., 79: 331-336. https://doi.org/10.1016/S03088146(02)00164-4

Fallah, A., Mohammad-Hasani, A. and Colagar, A.H., 2018. Zinc is an essential element for male fertility: A review of zn roles in men's health, germination, sperm quality, and fertilization. J. Reprod. Infert., 19: 69-81. Available from https://www.ncbi.nlm. nih.gov/pubmed/30009140

Free, M.J., Jaffe, R.A. and Morford, D.E., 1980. Sperm transport through the rete testis in anesthetized rats: Role of the testicular capsule and effect of gonadotropins and prostaglandins. Biol. Reprod., 22: 1073-1078. https://doi.org/10.1093/ biolreprod/22.5.1073

Gad-El-Hak, H.N. and Mobarak, Y.M., 2020. Copper oxychloride-induced testicular damage of adult albino rats and the possible role of curcumin in healing the damage. Environ. Sci. Pollut. Res., 27: 11649-11662. https://doi.org/10.1007/s11356-02007715-6

Girme, A., Bhalke, R., Ghogare, P., Tambe, V., Jadhav, R. and Nirmal, S., 2006. Comparative in vitro anthelmintic activity of mentha piperita and lantana camara from western india. Dhaka Univ. J. Pharm. Sci., 5: 5-7. https://doi.org/10.3329/dujps.v5i1.220

Goud, B.J. and Swamy, B., 2015. A review on history, controversy, traditional use, ethnobotany, phytochemistry and pharmacology of Artemisia absinthium linn. Int. J. Adv. Res. Eng. Appl. Sci., 4: 77-107.

Gupta, R., Sharma, R., Sharma, A., Bhatnager, A., Dobhal, M., Joshi, Y. and Sharma, M., 2002. Effect of alstonia scholaris bark extract on testicular function of wistar rats. Asian J. Androl., 4: 175178.

Hammond, J., Fielding, D. and Bishop, S., 1997. Prospects for plant anthelmintics in tropical veterinary medicine. Vet. Res. Commun., 21: 213228. https://doi.org/10.1023/A:1005884429253

Handelsman, D.J., Conway, A., Howe, C.J., Turner, L. and Mackey, M.-A., 1996. Establishing the minimum effective dose and additive effects of depot progestin in suppression of human spermatogenesis by a testosterone depot. J. Clin. Endocrinol. Metab., 81: 4113-4121. https://doi. org/10.1210/jcem.81.11.8923869 
Hayat, M.Q., Khan, M.A., Ashraf, M. and Jabeen, S., 2009. Ethnobotany of the genus artemisia $l$. (Asteraceae) in Pakistan. https://www.ncbi.nlm. nih.gov/pmc/articles/PMC3103284/; https://www. ncbi.nlm.nih.gov/pmc/articles/PMC4977869/; https://www.ncbi.nlm.nih.gov/pmc/articles/ PMC6010824/. https://doi.org/10.17348/ era.7.0.147-162

Huang, Z., Zhenghai, H., Zhenghai, H., Huang, Z. and Gutterman, Y., 2000. Structure and function of mucilaginous achenes of Artemisia monospermainhabiting the negev desert of israel. Israel J. Pl. Sci., 48: 255-266. https://doi. org/10.1560/49G5-CNE7-H6UD-PWVW

Johari, N., Ismail, I., Sulaiman, M., Abas, F. and Shaari, K., 2015. Acute toxicity and metabolomics analysis of hypocholesterolemic effect of Mentha piperita aqueous extract in wistar rats. Int. J. appl. Res. Nat. Prod., 8: 1-11.

Kermode, G., 1972. Food additives. Sci. Am., 226: 15-21. https://doi.org/10.1038/scientificamerican0372-15

Kordali, S., Cakir, A., Mavi, A., Kilic, H. and Yildirim, A., 2005. Screening of chemical composition and antifungal and antioxidant activities of the essential oils from three turkish Artemisia species. J. Agric. Fd. Chem., 53: 1408-1416. https://doi.org/10.1021/ jf048429n

Kunnumakkara, A.B., Koca, C., Dey, S., Gehlot, P., Yodkeeree, S., Danda, D., Sung, B. and Aggarwal, B.B., 2009. Traditional uses of spices: An overview. In: Molecular targets and therapeutic uses of spices: Modern uses for ancient medicine. World Sci., pp. 1-24. https://doi. org/10.1142/9789812837912_0001

Li, N., Mruk, D.D., Lee, W.M., Wong, C.K. and Cheng, C.Y., 2016. Is toxicant-induced sertoli cell injury in vitro a useful model to study molecular mechanisms in spermatogenesis? In: Seminars in cell and developmental biology. Elsevier, pp. 141156. https://doi.org/10.1016/j.semcdb.2016.01.003

Mannan, A., Ahmed, I., Arshad, W., Asim, M.F., Qureshi, R.A., Hussain, I. and Mirza, B., 2010. Survey of artemisinin production by diverse Artemisia species in northern pakistan. Malaria J., 9: 310 . https://doi.org/10.1186/1475-2875-9-310

Mimica-Dukic, N. and Bozin, B., 2008. Mentha 1. species (Lamiaceae) as promising sources of bioactive secondary metabolites. Curr. Pharm. Dis., 14: 3141-3150. https://doi. org/10.2174/138161208786404245

Nageeb, A., Al-Tawashi, A., Emwas A.-H.M., Al-Talla, Z.A-H. and Al-Rifai, N., 2013. Comparison of
Artemisia annua bioactivities between traditional medicine and chemical extracts. Curr. Bioact. Compd., 9: 324-332. https://doi.org/10.2174/1573 40720904140404151439

Nalbantsoy, A., Erel, Ş.B., Köksal, Ç., Göçmen, B., Yıldız, M.Z. and Yavaşoğlu, N.Ü.K., 2013. Viper venom induced inflammation with montivipera xanthina (gray, 1849) and the anti-snake venom activities of Artemisia absinthium 1. In rat. Toxicon, 65: 34-40. https://doi.org/10.1016/j. toxicon.2012.12.017

Ogbuewu, I.P., Unamba-Oparah, I.C., Odoemenam, V.U., Etuk, I.F. and Okoli, I.C., 2011. The potentiality of medicinal plants as the source of new contraceptive principles in males. N. Am. J. med. Sci., 3: 255. https://doi.org/10.4297/ najms.2011.3250

Oppenheimer, A., Cifrese, R., Hussein, M.M. and Corsello, V., 1990. Flavor enhancing and increasing efficacy of cough drops. Google Patents.

Pan, S.-Y., Litscher, G., Gao, S.-H., Zhou, S.-F., Yu, Z.L., Chen, H.-Q., Zhang, S.-F., Tang, M.-K., Sun, J.-N. and Ko, K.-M., 2014. Historical perspective of traditional indigenous medical practices: The current renaissance and conservation of herbal resources. Evid. Based Complement. Altern. Med., https://doi.org/10.1155/2014/525340

Pathak, A., Katiyar, R. and Sharma, D., 2014. Anatomy of the mediastinum testis of goat (capra hircus) a temporal study. Indian J. Vet. Anat., 26: 115-117.

Pradhan, D.K., Mishra, M.R., Mishra, A., Panda, A.K., Behera, R.K., Jha, S. and Choudhury, S., 2013. A comprehensive review of plants used as contraceptives. Int. J. Pharm. Sci. Res., 4: 148.

Ramezani, M., Fazli-Bazzaz, B., Saghafi-Khadem, F. and Dabaghian, A., 2004. Antimicrobial activity of four Artemisia species of iran. Fitoterapia, 75: 201203. https://doi.org/10.1016/j.fitote.2003.11.006

Riahi, L., Chograni, H., Elferchichi, M., Zaouali, Y., Zoghlami, N. and Mliki, A., 2013. Variations in tunisian wormwood essential oil profiles and phenolic contents between leaves and flowers and their effects on antioxidant activities. Ind. Crops Prod., 46: 290-296. https://doi.org/10.1016/j. indcrop.2013.01.036

Ribnicky, D., Poulev, A., Watford, M., Cefalu, W. and Raskin, I., 2006. Antihyperglycemic activity of tarralin ${ }^{\mathrm{TM}}$, an ethanolic extract of Artemisia dracunculus 1. Phytomedicine, 13: 550-557. https:// doi.org/10.1016/j.phymed.2005.09.007

Rich, K.A., Kerr, J.B. and de Kretser, D.M., 1979. Evidence for leydig cell dysfunction in rats with 
seminiferous tubule damage. Mol. cell. Endocrinol., 13: 123-135. https://doi.org/10.1016/03037207(79)90013-3

Salah, S.M. and Jäger, A.K., 2005. Two flavonoids from Artemisia herba-alba asso with in vitro gabaa-benzodiazepine receptor activity. $J$. Ethnopharmacol., 99: 145-146. https://doi. org/10.1016/j.jep.2005.01.031

Scarano, W., Messias, A., Oliva, S., Klinefelter, G. and Kempinas, W., 2006. Sexual behaviour, sperm quantity and quality after short-term streptozotocininduced hyperglycaemia in rats. Int. J. Androl., 29: $\quad 482-488$. https://doi.org/10.1111/j.13652605.2006.00682.x

Sessou, P., Farougou, S. and Sohounhloué, D., 2012. Major component and potential applications of plant essentials oils as natural food preservatives: A short review research results. Int. J. Biosci., 2: 45-57. https://doi.org/10.17265/2159-5828/2012.01.001

Sharma, N. and Jacob, D., 1996. Fertility suppression of the male mouse after administration of mint leaf extract. Phytother. Res., 10: 175-177. https://doi.org/10.1002/ (SICI) 1099-1573(199603)10:2<175::AIDPTR800>3.0.CO;2-7

Sharma, N. and Jocob, D., 2001. Anti-fertility investigation and toxicological screening of the petroleum ether extract of the leaves of mentha arvensis 1 . In male albino mice. J. Ethnopharmacol.,
75: $\quad 5-12 . \quad$ https://doi.org/10.1016/S03788741(00)00362-7

Smith, H.M., 2010. Effects of artemisia afra and artemisia absinthium on fertility of male mice exposed to increased ambient temperatures for 24 $h$. University of Missouri Columbia.

Struck, M.B., Andrutis, K.A., Ramirez, H.E. and Battles, A.H., 2011. Effect of a short-term fast on ketamine-xylazine anesthesia in rats. J. Am. Assoc. Lab. Anim. Sci., 50: 344-348. Available from https://www.ncbi.nlm.nih.gov/pubmed/21640029

Tan, R.X., Zheng, W. and Tang, H., 1998. Biologically active substances from the genus Artemisia. Planta Med., 64: 295-302. https://doi. org/10.1055/s-2006-957438

Tseng, L.-H., Lee, C.-W., Pan, M.-H., Tsai, S.-S., Li, M.-H., Chen, J.-R., Lay, J.-J. and Hsu, P.-C., 2006. Postnatal exposure of the male mouse to $2,2^{\prime}, 3$, $3^{\prime}, 4,4^{\prime}, 5,5^{\prime}, 6,6^{\prime}$-decabrominated diphenyl ether: Decreased epididymal sperm functions without alterations in DNA content and histology in testis. Toxicology, 224: 33-43. https://doi.org/10.1016/j. tox.2006.04.003

Wong, W.Y., Thomas, C.M., Merkus, J.M., Zielhuis, G.A. and Steegers-Theunissen, R.P., 2000. Male factor subfertility: Possible causes and the impact of nutritional factors. Fertil. Steril., 73: 435-442. https://doi.org/10.1016/S0015-0282(99)00551-8 